\title{
PREGNANT WOMEN'S KNOWLEDGE ABOUT HIGH RISK IN PREGNANCY
}

\author{
Annisa Citrasari Dewi ${ }^{1}$, Ermiati $^{2}$, Nur Oktavia Hidayati ${ }^{3}$ \\ ${ }^{1,2,3}$ Faculty Of Nursing, Universitas Padjadjaran, Bandung, Indonesia \\ Correspondence: ermiati@unpad.ac.id
}

\begin{abstract}
A high-risk pregnancy is a condition that increases the risk of complications in pregnant women and fetuses compared to normal pregnancies. One key to preventing high-risk in pregnancy is women's knowledge. This study aimed to describe the knowledge of pregnant women about high-risk pregnancies in the PHC Ganeas, Sumedang. The study was a descriptive quantitative research. The number of samples was 146 pregnant women who visited the PHC of Ganeas. The samples were selected using es using stratified random sampling technique. The instrument of this study used a questionnaire consisting of 50 statements. The results showed that 61 respondents $(41.0 \%)$ were categorized into high-risk pregnancies. The levels of knowledge were 131 respondents $(89.7 \%)$ had moderate knowledge, 7 respondents $(4.8 \%)$ had good knowledge, and 8 respondents $(5.5 \%)$ had insufficient knowledge. The conclusion in this study is that the majority of respondents belong to high-risk pregnancies, and have a moderate level of knowledge. Knowledge of pregnant women in the PHC of Ganeas should be improved by developing an extension program and information about high-risk pregnancies.

Keywords: pregnant women, high-risk pregnancy, knowledge
\end{abstract}

\section{INTRODUCTION}

The Maternal Mortality Rate (MMR) is one indicator of a country's health status. The Indonesian Demographic and Health Survey (IDHS) in 2012 showed a significant increase in MMR, which was 359 maternal deaths per 100,000 live births. In 2015 according to the results of the Intercensal Population Survey (SUPAS), MMR showed a decline to 305 maternal deaths per 100,000 live births. However, this showed that MMR in Indonesia is still high (RI Ministry of Health, 2016), due to the Millennium Development Goals (MDGs) target, the MMR in Indonesia should be 102 per 100,000 KH in 2015 (WHO, 2013). The high maternal mortality rate in Indonesia is related to the number of pregnant women who experience high-risk pregnancies (Sukmo, 2014).

West Java is a province with the highest contributing maternal mortality in Indonesia.

From 2014 to 2015, there was a significant increase in maternal mortality from 748 cases to 823 cases. In addition, the increase in infant mortality in 2014 was 3098 to 3369 cases in 2015. In West Java Province, on average there were 2 mothers and 9 baby's deaths every day (West Java Health Office, 2015). Sumedang Regency is one district in West Java, the 
number of maternal deaths was as many as 8 people in 2013, and in 2016 the cases increased become 17 deaths (Health Office Sumedang, 2017). This showed that within 3 years there has been an increase in maternal mortality rates of more than $100 \%$ in Sumedang Regency. In addition, the District Health Office Sumedang noted that there were $20 \%$ of pregnant women indicated in the high-risk category which are 4,157 women from 20,786 pregnant women (Health Office Sumedang, 2016).

According to Kusmarjadi (2008) in (Riftana, 2013), the causes of high maternal mortality were closely related to high-risk pregnancies. This was evident that the highest maternal mortality causes in Indonesia during 2010-2013 were due to bleeding and hypertension. In addition, the indirect causes of death also had a significant role in causing maternal deaths approximately $40.8 \%$ in 2013 . To overcome the problem of maternal and infant mortality, approaches were made by health workers to mothers, families, and communities who emphasized maternal empowerment and family and also involve the active role of the community (Prasetyawati, 2012). In 2007, the government launched a Maternity and Complication Prevention Planning Program (P4K) to help health professionals, women, family, and community in monitoring the condition and development of pregnant women and the delivery plan (Sokhiyatun, 2013). In addition, the government also established a program namely the 1000 First Days of Birth (1000 HPK) which is aimed to improve nutrition for pregnant women, post-partum women, newborns, and children under the age of 2 years. The First 1000 Day Birth Program is focused on counseling related to meet nutritional needs in the first 1000 days of life (golden period).

The preliminary study found the PHC in Sumedang district with the highest number of maternal deaths in 2016 was the PHC of Ganeas, there were 4 cases (history of a long labor, heart disease, hypertension, and bleeding). In the PHC of Ganeas, there were 11 pregnant women at high-risk conditions in August 2017, and 12 pregnant women with high- 
risk factors in September 2017. The most common complications in 2017 were premature rupture of membranes $(n=16)$ and hypertension in pregnancy $(n=24)$.

Many factors caused of death in pregnancy, one of them is the lack of knowledge of pregnant women regarding the types of complications in pregnancy, limited knowledge of the importance of ANC to health services (Febriyani, 2015). According to Elverawati (2008) in (Yuliastuti, 2015), one of the factors that influence maternal mortality is the knowledge, attitudes, and behavior of women during pregnancy. Knowledge is the key to overcoming a risky pregnancy. The purpose of this study was to examine the knowledge of pregnant women about high-risk sign and symptoms in pregnancy.

\section{METHODS}

The design of this study was a quantitative descriptive research with variable knowledge of pregnant women about high-risk pregnancy. The population in this study were all pregnant women who were recorded at the PHC of Ganeas, Sumedang, there were 229 women. The sample in this study was 146 pregnant women who were selected using a stratified quota sampling technique. This study used an instrument consisting of 50 statements with 4 indicators. The instrument has been tested for content and constructs. The reliability value was 0.973 and the validity value was $0.465-0.889$ ( $\mathrm{r}$ table $=0.4227$ ). The procedure for collecting data was to distribute questionnaires via cadres on May 2018.

\section{RESULTS}

Table 1. Characteristic of Pregnant Women

\begin{tabular}{lcc}
\hline \multicolumn{1}{c}{ Characteristic } & $(\%)$ & $\mathrm{f}$ \\
\hline Age & 36 & \\
$<20$ & 91 & 24.7 \\
$20-35$ & 19 & 62.3 \\
$\geq 35$ & & 13.0 \\
Age of Pregnancy: & 66 & 45.2 \\
Trimester 1 & 49 & 33.6 \\
Trimester 2 & & \\
\hline
\end{tabular}




\begin{tabular}{|c|c|c|}
\hline Trimester 3 & 31 & 21.2 \\
\hline \multicolumn{3}{|l|}{ Pregnancy: } \\
\hline$<4$ & 129 & 88.4 \\
\hline$>4$ & 17 & 11.6 \\
\hline \multicolumn{3}{|l|}{ BMI: } \\
\hline$>30$ (Obese) & 4 & 2.7 \\
\hline $25-29.9$ (Preobese) & 27 & 18.5 \\
\hline $18.5-24.9$ (Normal) & 69 & 47.3 \\
\hline$<18.5$ (Underweight) & 46 & 31.5 \\
\hline \multicolumn{3}{|l|}{ Length of perinatal period } \\
\hline$<2$ & 14 & 9.5 \\
\hline $2-5$ & 130 & 89.1 \\
\hline$>5$ & 2 & 1.4 \\
\hline \multicolumn{3}{|l|}{$\mathrm{Hb}:$} \\
\hline$<11$ & 57 & 39.0 \\
\hline$\geq 11$ & 89 & 61.0 \\
\hline \multicolumn{3}{|l|}{ Blood pressure } \\
\hline$<140 / 90 \mathrm{mmHg}$ & 105 & 71.9 \\
\hline$\geq 140 / 90 \mathrm{mmHg}$ & 41 & 28.1 \\
\hline \multicolumn{3}{|l|}{ History of abortus } \\
\hline No history & 120 & 82.2 \\
\hline History & 26 & 17.8 \\
\hline None & 146 & 100.0 \\
\hline \multicolumn{3}{|l|}{ History of childbirth: } \\
\hline Normal & 77 & 52,7 \\
\hline Premature & 5 & 3.4 \\
\hline \multicolumn{3}{|c|}{ Interventions (SC, Vacuum, } \\
\hline Forcep) & 11 & 7,5 \\
\hline \multicolumn{3}{|l|}{ Education: } \\
\hline Basic (SD \& SMP) & 47 & 32,2 \\
\hline Middle (SMA) & 83 & 56.8 \\
\hline \multicolumn{3}{|c|}{ High (D1, D2, D3, D4, S1, S2, } \\
\hline S3) & 16 & 11.0 \\
\hline \multicolumn{3}{|l|}{ Work status: } \\
\hline Housewife & 110 & 75.3 \\
\hline Businessman & 23 & 15.8 \\
\hline Government employees & 13 & 8.9 \\
\hline \multicolumn{3}{|l|}{ Income per month } \\
\hline$<$ Rp. 2.600.000,- & 72 & 49.3 \\
\hline$>$ Rp. 2.600.000,- & 77 & 52.7 \\
\hline
\end{tabular}

Table 1 shows that the majority of respondents aged 20-35 years was 84 respondents (71.2\%) and 66 of them (45.2\%) were in the 1st trimester of pregnancy. More than half of respondents $(n=129)$ had a history of pregnant $<4.89$ respondents $(61.0 \%)$ had HB levels $\geq$ 11. Furthermore, it was known that more than half of the respondents had blood pressure during pregnancy $<140 / 90 \mathrm{mmHg}$ as many as 105 respondents $(71.9 \%)$ and only a small proportion of respondents who had experienced abortion 
$(17.8 \%)$

The level of knowledge of respondents about high-risk pregnancies present in table 2

Table 2. Levels of Knowledge of High-Risk Pregnancy in Pregnant Women

\begin{tabular}{|c|c|c|}
\hline Level & Frequency (f) & $\mathrm{n}(\%)$ \\
\hline$\overline{\text { Good }}$ & 7 & 4,8 \\
\hline Moderate & 131 & 89,7 \\
\hline Insufficient & 8 & 5,5 \\
\hline
\end{tabular}

Table 2 describes that more than half $(89.7 \%)$ respondents had a moderate level of knowledge about high-risk pregnancies $(n=131) .7$ respondents $(4.8 \%)$ had a good knowledge and 8 of them (5.5\%) had insufficient knowledge about high-risk pregnancies.

The level of knowledge of respondents regarding high-risk pregnancy based on each indicator.

Table 3. The Level of Knowledge Based on Indicators

\begin{tabular}{lcc}
\hline \multicolumn{1}{c}{ Indicator } & f & $\%$ \\
\hline Definition of high-risk pregnancy: & 133 & 91,1 \\
Good & 13 & 8,9 \\
Insufficient & & \\
Complications and risk factors & 11 & 7,5 \\
High-Risk Pregnancy: & 97 & 66,4 \\
Good & 38 & 26,0 \\
Moderate & & \\
Insufficient & 3 & 2,1 \\
Signs of symptoms of high-risk pregnancy: & 70 & 47,9 \\
Good & 73 & 50,0 \\
Moderate & & \\
Insufficient & 47 & 32,2 \\
Prevention to reduce complications: & 80 & 54,8 \\
Good & 19 & 13.0 \\
Moderate & & \\
Insufficient &
\end{tabular}

Table 3 describes respondents who have good knowledge of high-risk pregnancy were 133 respondents $(91.1 \%)$ and more than half of respondents (97) had moderate knowledge. Half of the respondents had insufficient knowledge of 73 respondents (50\%). Knowledge about prevention to reduce pregnancy complications was known by 80 respondents $(54.8 \%)$. 


\section{DISCUSSION}

After analyzing the knowledge variable, it was found that a small percentage of respondents had good knowledge. Knowledge would change the attitude of pregnant women to their pregnancies, pregnant women who have good knowledge would have better understand about their pregnancies including increasing their adherence related to antenatal care. This is in accordance with Allport's explanation in (Notoatmodjo, 2012) which states that knowledge, thought processes, and beliefs play an important role in forming a person's attitude. If someone's knowledge is good, there is a possibility that someone's attitude would be good too and vice versa. In line with the study, Damayanti \& Nur's (2009) study stated that there is a significant relationship between the levels of knowledge of mothers with adherence to antenatal care visits. This study found that more than half of the respondents have the moderate knowledge level of high-risk pregnancies. Pregnant women who have moderate knowledge would have a better maintain their pregnancy compared to pregnant women with poor knowledge. However, pregnant women who have moderate knowledge should increase their knowledge to a good level, so they have a good attitude towards their pregnancy. Hasanah's (2017) study showed that a half of respondents who had moderate knowledge carried out regular antenatal care checks, and a half of them did irregular ANC. Whereas. in the group of women with a good knowledge level, all respondents conduct regular antenatal care visits. This showed that pregnant women with moderate knowledge of high-risk pregnancy should enhance their adherence in carrying out antenatal care examinations.

A small percentage of respondents have poor knowledge of high-risk pregnancy signs and symptoms. Pregnant women who have poor knowledge may tend to ignore the problem of pregnancy compared to pregnant women who have moderate and good knowledge. Maidelwita's (2010) stated that there is a significant relationship between the level of knowledge of pregnant women and high-risk pregnancies. The lower the level of knowledge 
of pregnant women about high-risk pregnancy, the more likely the pregnancy is at risk. According to Nursalam \& Efendi (2008), the high and low of one's knowledge is influenced by several factors, including education, work, age, experience, culture, and information. Most respondents were in the early adult age category (20-35 years) and had moderate knowledge. Increasing one's age would affect physical and psychological changes. Physical changes include changes in size, proportion, and the maturation of various organs. The psychological changes show from the level of thinking, individuals become more mature (Mubarak, 2007). Starting at age 20, there are cognitive changes including richer, more dynamic and complex.

One factor that affects knowledge is the experience. Experience is an event experienced by someone in their environment (Nursalam \& Efendi, 2008). More than half of the respondents have had previous pregnancy experience. Haryanti (2008) stated that the level of knowledge regarding the danger signs of pregnancy of multigravida women was better than primigravida women. In this study the majority of respondents had moderate knowledge, this could occur because the number of experiences of multigravida pregnant women was greater than that of primigravida pregnant women because they had been pregnant before and had been received a counseling. This shows that individuals' experience of something affects knowledge.

Other factors that influence knowledge are environmental and occupational cultural factors. Culture in every place would be influenced to someone and would have an impact on individuals' knowledge and attitude (Nursalam \& Efendi, 2008). The social environment of Ganeas Village is a conducive environment with Sundanese culture. This culture had an influence on the local leader such as pro-active towards health. This can be seen from the condition of the number of visitors in the posyandu program every month. Health cadres in Posyandu were active in socializing health behavior to pregnant women. In addition, most of the respondents in this study were housewives, so they may have a lot of free time to be able 
to pay attention to their pregnancies. They also participate in health education programs including about their pregnancies that conducted by cadres. This situation is aa good opportunity to transfer information from health workers and pregnant women.

In this study, more than half of the respondents attended senior high school. According to Mubarak (2007), the higher the education of a person, the easier for someone to absorb information. In opposite, if a person has a low level of education, it may prevent someone from receiving new information and values. Mothers who have a higher level of formal education tend to have more knowledge than mothers with lower levels of formal education. But it does not mean mothers who have a low level of formal education have low knowledge of health, as health education is not only obtained from formal education (Wawan \& Dewi, 2010). This is evident from the results of the study that one respondent had a low level of formal education but she well-informed of health knowledge. This is possible because many factors identified as influencing factors of health knowledge including environment, experience, and technology. The fact that information technology has developed and spread information easily including health.

The results showed that the majority of respondents had good knowledge about the definition of high-risk pregnancy. Pregnant women who have knowledge would also have a good attitude towards pregnancy compared to pregnant women with low knowledge. Widya (2014) stated that there is a significant relationship between knowledge about the high risk of pregnancy and regular pregnancy checks. The better the knowledge of pregnant women about the high risk of pregnancy, the more regularly pregnant women in their pregnancy checks. It is known that most respondents have moderate knowledge about complications and high-risk pregnancy factors. The better the level of knowledge of mothers about high-risk pregnancy factors affect pregnant women's understanding of pregnancy, determine the actions, and 
avoid high-risk factors for pregnancy. In line with research (Permatasari, 2012) which stated that there is a significant relationship between knowledge and type of delivery.

38 respondents had insufficient knowledge about complications and risk factors for high-risk pregnancies. Pregnant women who have low knowledge about high-risk pregnancy risk factors would be more ignorant about their pregnancy and maybe they cannot avoid highrisk pregnancies. This is in line with the research (Esposito et al., 2015) which stated that if pregnant women have low knowledge about high-risk pregnancy factors, then the pregnant woman would not change her attitudes and behavior. In Italy, pregnant women with low knowledge of pregnancy factors are at high risk of smoking, drinking alcoholic beverages and not avoiding high-risk pregnancy factors. In line with research (Permatasari, 2012) stated that pregnant women who have a level of lack of knowledge about high-risk pregnancy factors have a 5.6 times greater risk of giving birth by actions (surgery, vacuum, and forceps) compared to mothers with a good knowledge.

Signs and symptoms of high-risk pregnancy are known by some pregnant women. In line with the research (Yanti \& Ayu, 2016) which suggested that the better the knowledge of pregnant women about the symptoms of the danger of pregnancy, pregnant women would be more obedient in carrying out antenatal care. Mothers who have a high level of knowledge have a three times greater chance of choosing health facilities as a place of birth compared to those with low knowledge (Putri, 2016). Half of the respondents have insufficient knowledge about the signs and symptoms of a high risk of pregnancy. Pregnant women who have low knowledge about signs symptoms of high-risk pregnancy would tend to take no notice of their pregnancy so they do not comply with antenatal care visits. Hasanah's (2017) study stated that there is a relationship between the knowledge of pregnant women regarding the danger signs of pregnancy with regular pregnancy checks. Pregnant women who have low 
knowledge about the danger signs of pregnancy are likely to be irregular in carrying out antenatal care.

More than half of the respondents have moderate knowledge about preventing complications in pregnancy. Pregnant women who have high knowledge about the prevention of pregnancy complications have a positive attitude in preventing pregnancy complications and determine the right place for delivery. In the study (Nasriyah \& Tristanti, 2016) stated that the better the level of knowledge of pregnant women about pregnancy planning and preventing of complications $(\mathrm{P} 4 \mathrm{~K})$, the attitude of pregnant women were better in an effort to pregnancy planning and preventing complications. This is in line with the research (Pertiwi, 2013) which mentioned the relationship between knowledge and attitudes of pregnant women in preventing complications with planning the pregnancy. Pregnant women who have low knowledge about prevention of complications may have a lack attitude in making efforts to prevent complications, determine the place of delivery, and the low compliance of pregnant women in conducting antenatal care visits. In the study (Yanti \& Ayu, 2016) stated that the lower the level of knowledge of pregnant women about signs of symptoms and complications of pregnancy, the lower the level of adherence in carrying out antenatal care.

\section{CONCLUSION}

According to the results of the study, it can be concluded that the knowledge of pregnant women about the high risk of pregnancy is varied, however, it dominated by moderate knowledge. Therefore, the knowledge of pregnant women in the working area of the PHC Ganeas should be increased by developing an extension program and information on highrisk pregnancies. 


\section{REFERENCES}

Damayanti, E., \& Nur, W. (2009). Hubungan Tingkat Pengetahuan Ibu Hamil tentang Resiko Tinggi Kehamilan dengan Kepatuhan Kunjungan Antenatal Care di RSUD Pandan Arang Boyolali. Universitas Muhammadiyah Surakarta, 2, 174-182.

Esposito, G., Ambrosio, R., Napolitano, F., \& Di Giuseppe, G. (2015). Women's Knowledge, Attitudes And Behavior About Maternal Risk Factors In Pregnancy. PLoS ONE, 10(12), 1-12. https://doi.org/10.1371/journal.pone.0145873

Febriyani, T., Syahlani, A., \& Muliyawan, A. (2015). Gambaran Pengetahuan Dan Sikap Ibu Hamil Tentang Kehamilan Resiko Tinggi Di Puskesmas Pekauman Banjarmasin. STIKES Sari Mulia Banjarmasin, 3, 18-31.

Haryanti, R. S. (2008). Perbedaan Tingkat Pengetahuan Antara PrimiGravida dan Multigravida Tentang Tanda Bahaya Kehamilan Di Puskesmas Sibela Surakarta. Universitas Sebelas Maret.

Hasanah, A. (2017). Hubungan Pengetahuan Ibu Hamil Tentang Tanda Bahaya Kehamilan Trimester Tiga dengan Keteraturan Pemeriksaan Kehamilan Di Puskesmas Mergangsan Yogyakarta. Fakultas Ilmu Kesehatan Universitas As’ Aisyiyah.

Kementerian Kesehatan RI. (2016). Profil Kesehatan Indonesia 2015. https://doi.org/351.077 Ind

Maidelwita, Y. (2010). Faktor-Faktor Yang Berhubungan Dengan Kehamilan Resiko Tinggi Di Puskesmas Nanggalo Padang. Stikes Mercubaktijaya Padang.

Mubarak. (2007). Promosi Kesehatan Sebuah Pengamatan Proses Belajar Mengajar dalam Pendidikan. Yogyakarta: Graha Ilmu. 
Nasriyah, \& Tristanti, I. (2016). Upaya Pencegahan Kehamilan dan Persalinan Berdasarkan Karakteristik Ibu Hamil Di Kabupaten Kudus. Universitas Muhammadiyah Kudus, 1-12.

Notoatmodjo, S. (2012). Promosi Kesehatan Teori \& Aplikasi (Revisi). Jakarta: Rineka Cipta.

Nursalam, \& Efendi, F. (2008). Pendidikan Dalam Keperawatan. Jakarta: Salemba Medika. Permatasari, A. (2012). Hubungan Antara Pengetahuan Faktor Kehamilan dan Jenis Persalinan. Fakultas Kedokteran Universitas Sebelas Maret.

Pertiwi, D. (2013). Hubungan Pengetahuan Dan Sikap Ibu Hamil Tentang Program Perencanaan Persalinan dan Pencegahan Komplikasi (P4K) Sebagai Upaya Pencegahan Komplikasi Kehamilan Di Kelurahan Kutambaru Kabupaten Langkat. Universitas Sumatera Utara.

Prasetyawati, A. E. (2012). Kesehatan Ibu dan Anak (KIA) dalam Millenium Development Goals (MDG'S). Yogyakarta: Nuha Medika.

Putri, M. D. (2016). Faktor Faktor Yang Berhubungan Dengan Pemilihan Tempat Persalinan. Jurnal Kesehatan Masyarakat, 4(April), 55-67.

Riftana, F. D. C. (2013). Hubungan Tingkat Pengetahuan Tentang Kehamilan Risiko Tinggi Dengan Persiapan Persalinan Pada Ibu Hamil Usia Remaja Di Wilayah Kerja Puskesmas Bangsalsari Kabupaten Jember. Program Studi Ilmu Keperawatan Universitas Jember.

Society for Maternal-Fetal Medicine. (2010). High-Risk Pregnancy Care, Research, And Education For Over 35 Years, 1-34. Retrieved from papers2://publication/uuid/F83F6842-D7D2-4D08-8181-3F077753767E 
Sokhiyatun, LaksmonoWidagdo, \& Sriatmi, A. (2013). Pelaksanaan Program Perencanaan Persalinan dan Pencegahan Komplikasi (P4K) Ditinjau dari Aspek Bidan Desa sebagai Pelaksana di Kabupaten Jepara Tahun 2012. Jurnal Manajemen Kesehatan Indonesia Volume, 1(1), 47-53. Retrieved from http://eprints.undip.ac.id/39862/2/Abstrak_Sokhiyatun_MKIA_Januari_2013.pdf

Sukmo, R., Islamudin, R. A., Subha, I., \& Pamungkas, A. (2014). ICE ( Intensive Community Empowerment ) Sebagai Solusi Upaya Mencegah Kenaikan Angka Kematian Ibu ( AKI ) Sebagai Program Percontohan Di Wilayah Kelurahan Bangetayu Wetan Kecematan Genuk Kota Semarang. Disnakes, 4(4 April), 12-17.

Wawan, A., \& Dewi, M. (2010). Teori \& Pengukuran Pengetahuan, Sikap, dan Perilaku Manusia. Yogyakarta: Nuha Medika.

Widya, A. (2014). Hubungan Pengetahuan Dan Sikap Ibu Hamil Tentang Resiko Tinggi Kehamilan Dengan Keteraturan Pemeriksaan Kehamilan Di Wilayah Kerja Puskesmas Slawe Kabupaten Trenggalek. Jurnal UNS.

Yanti, R. D., \& Ayu, N. G. M. (2016). Hubungan Antara Pengetahuan Ibu Hamil Tentang Tanda Bahaya Dan Komplikasi Kehamilan Dengan Kepatuhan Kunjungan Antenatal Dan Pemilihan Tempat Bersalin Di Wilayah Tanah Sareal Bogor. Jurnal Ilmiah Kesehatan Diagnosis, 8(1), 2302-1721.

Yuliastuti, E. (2015). Pengetahuan Dan Sikap Ibu Hamil Terhadap Perencanaan Pertolongan Persalinan Dan Pencegahan Komplikasi (P4K). Jurnal Vokasi Kesehatan, 1, 142-145. 